\title{
ROLE OF PULMONARY REHABILITATION IN COPD PATIENTS
}

\author{
Bharathi Babu $K^{1}$, Prabhakaran Rathinam², Elamparithi $S^{3}$, Saravanavasan $R^{4}$
}

${ }_{1}^{1}$ Assistant Professor, Department of Pulmonology, Government Rajaji Hospital, Madurai.

${ }^{2}$ Associate Professor, Department of Pulmonology, Government Rajaji Hospital, Madurai.

${ }^{3}$ Assistant Professor, Department of Pulmonology, Government Rajaji Hospital, Madurai.

${ }^{4}$ Assistant Professor, Department of Pulmonology, Government Rajaji Hospital, Madurai.

\section{ABSTRACT}

\section{BACKGROUND}

Chronic obstructive pulmonary disease (COPD) is associated with reduction in daily physical activity that contribute to the patient's disability and poor health-related quality of life. Pulmonary rehabilitation plays an essential role in the management of symptomatic patients with COPD by breaking the vicious circle of dyspnoea-decreased activity-deconditioning-isolation. Several randomised studies and meta-analyses greatly established the benefits of pulmonary rehabilitation. Pulmonary rehabilitation is recommended in a number of influential guidelines. In this study, we have compared the symptomatic wellbeing of COPD patients attending Pulmonology OP at Govt. Rajaji Hospital, Madurai.

In this study, we aim to evaluate the benefits of Pulmonary Rehabilitation in COPD patients who are on Pharmacological treatment (Standard of care management) for COPD.

\section{MATERIALS AND METHODS}

Total of 80 COPD (FEV1/FVC less than 0.7 with no reversibility after bronchodilators in Pulmonary Function Test) patients were taken with various degrees of obstruction (24- Mild, 32- Moderate, 24- Severe). The degree of obstruction was determined by FEV1 as per GOLD guidelines, FEV1 > 80- Mild, FEV1- Moderate and FEV1- Severe Obstruction. They were divided into two groups with 40 patients in each group (12- Mild, 16- Moderate, 12- Severe). One set of patients had only pharmacological treatment, whereas the other set had a combined pulmonary rehabilitation with pharmacological treatment. The improvement in Borg scale, Visual analogue scale, MMRC grading of dyspnea and 6-minute walk distance were compared between the two groups.

\section{RESULTS}

The group with combined pulmonary rehabilitation with pharmacological treatment had a significant improvement in dyspnea index and a significant improvement in the 6-minute walk distance. The values were statistically significant $(\mathrm{P}<0.05)$.

\section{CONCLUSION}

The group with combined pulmonary rehabilitation with pharmacological treatment had a significant improvement in dyspnea index and a significant improvement in the 6-minute walk distance. The values were statistically significant $(\mathrm{P}<0.05)$. The benefits of pulmonary rehabilitation were greater in patients with severe COPD. The more severe the obstruction, the greater the benefit.

\section{KEYWORDS}

Pulmonary Rehabilitation, COPD, Breathlessness Index.

HOW TO CITE THIS ARTICLE: Babu BK, Rathinam P, Elamparithi S, et al. Role of pulmonary rehabilitation in COPD patients. J. Evolution Med. Dent. Sci. 2017;6(65):4699-4703, DOI: 10.14260/Jemds/2017/1017

\section{BACKGROUND}

The prevalence of Chronic Obstructive Pulmonary Disease (COPD) is constantly increasing, ${ }^{1}$ while its incidence is growing in old age.2,3 COPD is also a leading cause of morbidity worldwide, particularly in developing countries. ${ }^{1}$ COPD is an obstructive and progressive airway disease associated with a significant reduction in physical activity and psychological problems, all of which contribute to the patient's disability and poor health-related quality of life (HRQoL). ${ }^{3}$ For a long time, the treatment of COPD has focused mainly on pharmacological improvement of the airway obstruction.

Financial or Other, Competing Interest: None.

Submission 21-07-2017, Peer Review 05-08-2017,

Acceptance 07-08-2017, Published 14-08-2017.

Corresponding Author:

Prabhakaran Rathinam,

Associate Professor,

Department of Pulmonology,

Government Rajaji Hospital, Madurai.

E-mail: drbabumdchest@gmail.com

DOI: $10.14260 /$ jemds $/ 2017 / 1017$
However, over the last two decades, there is development and use of non-pharmacological treatments such as pulmonary rehabilitation.

Pulmonary rehabilitation and pharmacological therapy are not competitive, but rather must work closely together if they are to result in a more successful outcome. The benefit of PR in patients with COPD in improving exercise capacity and quality of life in COPD patients has been widely established by randomised studies.4-8

\section{Pulmonary Rehabilitation will-}

- Help to improve your muscle strength, so you can use the oxygen you breathe more efficiently.

- Improve your general fitness and help you to cope better with feeling out of breath.

- Help you to feel stronger and fitter, and able to do more.

Pulmonary rehabilitation offers benefits for all patients suffering from a chronic respiratory disease of whatever origin, who have a decrease of pulmonary function, who are symptomatic and who have intolerance to effort in spite of an 
optimal pharmacological treatment. ${ }^{4-7}$ Previous trials have found Pulmonary Rehabilitation useful in COPD patients.

\section{Aims and Objectives}

To evaluate the benefits of Pulmonary Rehabilitation in COPD patients who are on Pharmacological treatment (Standard of care management) for COPD.

\section{MATERIALS AND METHODS}

Study Design

Non-Randomised Controlled Trial.

Study Period

January 2015 to June 2015.

Study Centre Government Rajaji Hospital, Madurai.

Study Population COPD patients attending Pulmonary Medicine OP at Govt. Rajaji Hospital Madurai, who are willing for the study.

Inclusion Criteria : COPD patients (FEV1/FVC less than 0.7 with no reversibility after bronchodilators in Pulmonary Function Test).

\section{Exclusion Criteria}

COPD patients with non-adherence to treatment, not on regular follow-up, psychiatric illness, dementia, associated uncontrolled cardiovascular disease and inability to do exercise (for orthopaedic or other reasons).

\section{Study Procedure}

It is a non-randomised controlled trial done at Department of Pulmonary Medicine, Govt. Rajaji Hospital, Madurai. Total of 80 patients attending Pulmonary Medicine- COPD clinic at Govt. Rajaji Hospital- Madurai, who were willing for the study were taken with various degrees of obstruction (24- Mild, 32Moderate, 24- Severe). The degree of obstruction were determined by FEV1 as per GOLD guidelines, FEV1 > 80- Mild, FEV1- Moderate and FEV1- Severe Obstruction. They were divided into two equal groups without randomisation with 40 patients in each group (12-Mild, 16- Moderate, 12- Severe). 40 patients were given pulmonary rehabilitation along with the usual pharmacological therapy they are on. The other group with 40 patients were given only pharmacological treatment without pulmonary rehabilitation. The improvement in Dyspnea (Borg and Visual Analogue scale) and exercise tolerance (6-minute walk test) and MMRC grading were assessed 8 weeks later and the results of two groups were compared.

\section{RESULTS}

\begin{tabular}{|c|c|c|c|}
\hline & $\begin{array}{c}\text { Control Group } \\
(n=40)\end{array}$ & $\begin{array}{c}\text { PR Group } \\
(n=40)\end{array}$ & P-value \\
\hline Borg Scale & $3.6 \pm 2.8$ & $4.2 \pm 2.2$ & 0.322 \\
\hline $\begin{array}{l}\text { Visual Analogue } \\
\text { Scale }\end{array}$ & $4.7 \pm 2.7$ & $4.7 \pm 2.5$ & 0.977 \\
\hline $\begin{array}{l}\text { 6-minute Walk } \\
\text { Distance }\end{array}$ & $386.5 \pm 153.2$ & $394.4 \pm 135.6$ & 0.808 \\
\hline \multicolumn{4}{|l|}{ MMRC Grading } \\
\hline 0 & $4(10.0)$ & - & \\
\hline 1 & $7(17.5)$ & $10(25.0)$ & \\
\hline 2 & 7 (17.5) & $4(10.0)$ & 0.220 \\
\hline 3 & $10(25.0)$ & $11(27.5)$ & \\
\hline 4 & $12(30.0)$ & $15(37.5)$ & \\
\hline
\end{tabular}

\begin{tabular}{|c|c|c|c|}
\hline & $\begin{array}{l}\text { Control } \\
\text { Group } \\
(n=40)\end{array}$ & $\begin{array}{l}\text { PR Group } \\
(n=40)\end{array}$ & P-value \\
\hline Borg Scale & $3.6 \pm 2.8$ & $2.5 \pm 2.1$ & 0.047 \\
\hline $\begin{array}{l}\text { Visual Analogue } \\
\text { Scale }\end{array}$ & $4.8 \pm 2.8$ & $3.4 \pm 2.4$ & 0.013 \\
\hline $\begin{array}{c}\text { 6-Minute Walk } \\
\text { Distance }\end{array}$ & $408.1 \pm 155.1$ & $490.2 \pm 132.0$ & 0.019 \\
\hline MMRC Grading & & & \\
\hline 0 & $4(10.0)$ & $10(25.0)$ & \multirow{5}{*}{0.048} \\
\hline 1 & $7(17.5)$ & $5(12.5)$ & \\
\hline 2 & 7 (17.5) & $14(35.0)$ & \\
\hline 3 & $10(25.0)$ & $6(15.0)$ & \\
\hline 4 & $12(30.0)$ & $5(12.5)$ & \\
\hline
\end{tabular}

\begin{tabular}{|c|c|c|c|}
\hline & Control Group & PR Group & P-value \\
\hline Mild COPD & $(n=12)$ & $(n=12)$ & \\
\hline Borg Scale & $1.0 \pm 0.5$ & $0.5 \pm 0.1$ & 0.011 \\
\hline $\begin{array}{c}\text { Visual Analogue } \\
\text { Scale }\end{array}$ & $1.8 \pm 0.6$ & $1.0 \pm 0.3$ & 0.001 \\
\hline $\begin{array}{l}\text { 6-Minute Walk } \\
\text { Distance }\end{array}$ & $581.6 \pm 24.4$ & $633.6 \pm 23.9$ & $<0.001$ \\
\hline MMRC Grading & & & \\
\hline 0 & 4 (33.3) & $10(83.3)$ & \multirow{5}{*}{$<0.001$} \\
\hline 1 & $6(50.0)$ & $2(16.7)$ & \\
\hline 2 & $2(16.7)$ & - & \\
\hline 3 & - & - & \\
\hline 4 & - & - & \\
\hline Moderate COPD & $(n=16)$ & $(n=16)$ & \\
\hline Borg Scale & $3.0 \pm 1.5$ & $2.0 \pm 1.0$ & 0.043 \\
\hline $\begin{array}{c}\text { Visual Analogue } \\
\text { Scale }\end{array}$ & $4.6 \pm 1.7$ & $3.1 \pm 1.3$ & 0.001 \\
\hline $\begin{array}{l}\text { 6-Minute Walk } \\
\text { Distance }\end{array}$ & $411.3 \pm 84.9$ & $493.9 \pm 66.2$ & 0.005 \\
\hline MMRC Grading & & & \\
\hline 0 & - & - & \multirow{5}{*}{$<0.001$} \\
\hline 1 & $1(6.3)$ & $3(18.8)$ & \\
\hline 2 & $5(31.3)$ & $10(62.5)$ & \\
\hline 3 & $7(43.8)$ & $3(18.8)$ & \\
\hline 4 & 3 (18.8) & - & \\
\hline Severe COPD & $(n=12)$ & $(n=12)$ & \\
\hline Borg Scale & $7.0 \pm 2.1$ & $5.2 \pm 1.6$ & 0.037 \\
\hline $\begin{array}{l}\text { Visual Analogue } \\
\text { Scale }\end{array}$ & $8.1 \pm 1.5$ & $6.2 \pm 1.7$ & 0.016 \\
\hline $\begin{array}{l}\text { 6-Minute Walk } \\
\text { Distance }\end{array}$ & $230.25 \pm 86.8$ & $341.83 \pm 93.4$ & 0.006 \\
\hline \multicolumn{4}{|l|}{ MMRC Grading } \\
\hline 0 & - & - & \multirow{5}{*}{$<0.001$} \\
\hline 1 & - & - & \\
\hline 2 & - & $4(33.3)$ & \\
\hline 3 & $3(25.0)$ & $3(25.0)$ & \\
\hline 4 & $9(75.0)$ & $5(41.7)$ & \\
\hline \multicolumn{4}{|c|}{$\begin{array}{l}\text { Table 3. Comparison of HRQL among Mild, } \\
\text { Moderate and Severe COPD Patients }\end{array}$} \\
\hline
\end{tabular}




\begin{tabular}{|c|c|c|}
\hline & $\begin{array}{c}\text { Patients on } \\
\text { Pharmacological } \\
\text { Therapy Alone }\end{array}$ & $\begin{array}{c}\text { Patients on } \\
\text { Pulmonary } \\
\text { Rehabilitation with } \\
\text { Pharmacological } \\
\text { Therapy }\end{array}$ \\
\hline Borg Scale & 4 & 4 \\
\hline $\begin{array}{c}\text { Visual Analogue } \\
\text { Scale }\end{array}$ & $4.7 \mathrm{~cm}$ & $4.9 \mathrm{~cm}$ \\
\hline $\begin{array}{c}\text { 6-Minute Walk } \\
\text { Distance }\end{array}$ & 386 & 394 \\
\hline $\begin{array}{c}\text { MMRC Dyspnea } \\
\text { Score }\end{array}$ & 3 & 3 \\
\hline \multicolumn{2}{|c|}{ Table 4. Comparison of Dyspnea Scores and 6-Minute } \\
Walk Distance of both the Groups at the Start of Study \\
\hline
\end{tabular}

\begin{tabular}{|c|c|c|}
\hline & $\begin{array}{c}\text { Patients on } \\
\text { Pharmacological } \\
\text { Therapy Alone }\end{array}$ & $\begin{array}{c}\text { Patients on } \\
\text { Pulmonary } \\
\text { Rehabilitation with } \\
\text { Pharmacological } \\
\text { Therapy }\end{array}$ \\
\hline Borg Scale & 4 & 3 \\
\hline $\begin{array}{c}\text { Visual Analogue } \\
\text { Scale }\end{array}$ & 4.9 & 3.4 \\
\hline $\begin{array}{c}\text { 6-Minute Walk } \\
\text { Distance }\end{array}$ & 405 & 490 \\
\hline $\begin{array}{c}\text { MMRC Dyspnea } \\
\text { Score }\end{array}$ & 3 & 2 \\
\hline $\begin{array}{c}\text { Table 5. Comparison of Dyspnea Scores and 6-Minute } \\
\text { Walk Distance of Both the Groups at the End of Study }\end{array}$ \\
\hline
\end{tabular}

\begin{tabular}{|c|c|c|}
\hline & $\begin{array}{c}\text { Patients on } \\
\text { Pharmacological } \\
\text { Therapy Alone }\end{array}$ & $\begin{array}{c}\text { Patients on } \\
\text { Pulmonary } \\
\text { Rehabilitation with } \\
\text { Pharmacological } \\
\text { Therapy }\end{array}$ \\
\hline Borg Scale & 1 & 0.5 \\
\hline $\begin{array}{c}\text { Visual Analogue } \\
\text { Scale }\end{array}$ & $1.9 \mathrm{~cm}$ & $1.1 \mathrm{~cm}$ \\
\hline 6-minute & 582 & 634 \\
\hline $\begin{array}{c}\text { MMRC Dyspnea } \\
\text { Score }\end{array}$ & 1 & 0 \\
\hline \multicolumn{2}{|c|}{$\begin{array}{c}\text { Table 6. Comparison of Dyspnea Scores and 6- } \\
\text { Minute Walk Distance of Mild COPD Patients } \\
\text { in Both the Groups at the End of Study }\end{array}$} \\
\hline
\end{tabular}

\begin{tabular}{|c|c|c|}
\hline & $\begin{array}{c}\text { Patients on } \\
\text { Pharmacological } \\
\text { Therapy Alone }\end{array}$ & $\begin{array}{c}\text { Patients on } \\
\text { Pulmonary } \\
\text { Rehabilitation with } \\
\text { Pharmacological } \\
\text { Therapy }\end{array}$ \\
\hline Borg Scale & 3 & 2 \\
\hline $\begin{array}{c}\text { Visual Analogue } \\
\text { Scale }\end{array}$ & 4.7 & 3.2 \\
\hline 6 Minute & 412 & 494 \\
\hline $\begin{array}{c}\text { MMRC Dyspnea } \\
\text { Score }\end{array}$ & 3 & 2 \\
\hline \multicolumn{2}{|c|}{$\begin{array}{c}\text { Table 7. Comparison of Dyspnea Scores and 6- } \\
\text { Minute Walk Distance of Moderate COPD Patients } \\
\text { in Both the Groups at the End of Study }\end{array}$} \\
\hline
\end{tabular}

\begin{tabular}{|c|c|c|}
\hline & $\begin{array}{c}\text { Patients on } \\
\text { Pharmacological } \\
\text { Therapy Alone }\end{array}$ & $\begin{array}{c}\text { Patients on } \\
\text { Pulmonary } \\
\text { Rehabilitation with } \\
\text { Pharmacological } \\
\text { Therapy }\end{array}$ \\
\hline Borg Scale & 7 & 5 \\
\hline $\begin{array}{c}\text { Visual Analogue } \\
\text { Scale }\end{array}$ & $8.1 \mathrm{~cm}$ & $6.3 \mathrm{~cm}$ \\
\hline 6 Minute & 231 & 342 \\
\hline $\begin{array}{c}\text { MMRC Dyspnea } \\
\text { Score }\end{array}$ & 4 & 3 \\
\hline \multicolumn{2}{|c|}{ Table 8. Comparison of Dyspnea Scores and 6- } \\
Minute Walk Distance of Severe COPD Patients \\
in Both the Groups at the End of Study
\end{tabular}

\section{Power of the Study}

We did not calculate the sample size properly in initial stage of the study. Based on the inclusion/exclusion criteria, we recruited all the patients coming to pulmonology OPD from so and so date at Govt. Rajaji Hospital. Instead of sample size calculation, we performed power of the study based on our results. We achieved $40 \%$ power in Borg scale, $67 \%$ power in VAS and $73 \%$ power in 6-minute walk distance.

\section{DISCUSSION}

The initial assessments include past medical history (including comorbidities), physical examination, the 6-minute walk test, pulmonary function tests and psychological evaluations. After selection, patients were randomised into 2 groups (40 in each group).

First group will continue with their Pharmacological treatment (Standard of care treatment for COPD) and their dyspnea scoring and 6-minute walk distance are recorded at the start of study and after 8 weeks (end of study).

Second group will get pulmonary rehabilitation in addition to their Pharmacological treatment (Standard of care treatment for COPD) and their dyspnea scoring and 6-minute walk distance are recorded at the start of study and after 8 weeks (end of study).

\section{Exercise Training}

Continuous and interval training as well as strength training may be regarded as the major exercise components of Pulmonary Rehabilitation. ${ }^{9}$ Endurance training is the most common exercise modality in COPD patients. The main objective is to improve aerobic exercise capacity as aerobic activities are part of many tasks. ${ }^{9}$

Lower extremity exercise training produces greater physiologic benefits in patients with COPD. The total effective training time should ideally be over 30 minutes. They vary from simply walking on a treadmill or around a track to more intense stair climbing. Most of the proven benefits of pulmonary rehab are shown in studies of people doing leg exercises. In clinical practice, symptom scores can be used to adjust the training load (eg. Borg score of 4 to 6 for dyspnea).10 For severely breathless patients, an interval training regime may be preferred.11 Here, the continuous exercise session is substituted by a succession of shorter high-intensity exercise periods alternated with low-tomoderate-intensity exercise recovery periods. 
Upper limb exercises include an arm cycle ergometer, free weights or elastic bands. All modes of arm exercise have been shown to increase arm endurance capacity by a clinically significant level compared with no arm training. ${ }^{12,13}$ The muscles in the upper body are important for breathing as well as for daily activities. Arm and chest exercises might include turning a crank against resistance or just lifting your arms against gravity.

\section{Strength Training}

Most pulmonary rehab exercises focus on building endurance. Adding strength training, such as lifting weights has been shown to be helpful as well.

\section{Respiratory Muscle Training}

Respiratory exercise using spirometer and pranayama are advised. Patients were trained to do pranayama for at least half an hour duration daily in addition to their usual physical activity and medications. ${ }^{14}$ Patients are encouraged to use incentive spirometer 6 times a day (2 - 3 minutes/ episode). Blowing through a mouthpiece against resistance may increase the strength of your breathing muscles. These exercises may be helpful for people with very weak breathing muscles.

After 8 weeks VAS for Dyspnea, Borg score, MMRC grading of Dyspnea and 6-minute walk distance of the two groups were compared. The data was entered in excel sheet and outcomes were measured in frequency and percentage.

\section{Visual Analogue Scale}

VAS dyspnea scale is a horizontal line, $100 \mathrm{~mm}$ in length and anchored by word descriptors at each end. The VAS dyspnea score uses "no shortness of breath at all" and "maximum shortness of breath." The patient marks on the line the point that they feel represents the perception of their current state of dyspnea. The distance $(\mathrm{mm})$ between the beginning of the horizontal line and this mark represents the degree of dyspnea perception.

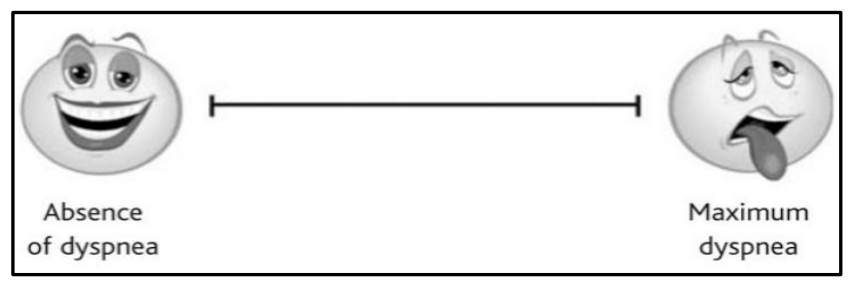

\begin{tabular}{|c|c|}
\hline Borg Scale & Level of Breathlessness \\
\hline 0 & Nothing at all \\
\hline 0.5 & Very very slight \\
\hline 1 & Very slight \\
\hline 2 & Slight \\
\hline 3 & Moderate \\
\hline 4 & Somewhat severe \\
\hline 5 & Severe \\
\hline 6 & Very severe \\
\hline 7 & \\
\hline 8 & Very very severe \\
\hline 9 & Maximum \\
\hline 10 & \\
\hline
\end{tabular}

\section{MMRC Dyspnea Scale}

\begin{tabular}{|c|c|}
\hline Grade & Description of Breathlessness \\
\hline 0 & I only get breathless with strenuous exercise. \\
\hline 1 & $\begin{array}{c}\text { I get short of breath when hurrying on level ground } \\
\text { or walking up a slight hill. }\end{array}$ \\
\hline 2 & $\begin{array}{c}\text { On level ground, I walk slower than people of the } \\
\text { same age because of breathlessness or have to stop } \\
\text { for breath when walking at my own pace. }\end{array}$ \\
\hline 3 & $\begin{array}{c}\text { I stop for breath after walking about 100 yards or } \\
\text { after a few minutes on level ground. }\end{array}$ \\
\hline 4 & $\begin{array}{r}\text { I am too breathless to leave the house or I am } \\
\text { breathless when dressing. }\end{array}$ \\
\hline
\end{tabular}

\section{6-Minute Walk Test}

The patient is made to sit at rest in a chair for at least 10 minutes before the test starts. Have the patient stand and rate their baseline dyspnea and overall fatigue using the Borg scale. Instruct the patient to walk as far as possible for 6 minutes. The patient is permitted to slow down, to stop and to rest as necessary. Patient may lean against the wall while resting, but resume walking as soon as they are able. Calculate the total distance walked, rounding to the nearest meter and record it. SpO2 is measured before and after the test.

\section{CONCLUSION}

There is definitely a good improvement in sense of wellbeing, better exercise tolerance and decrease in shortness of breath in the group, which combines pulmonary rehabilitation and pharmacological treatment compared to the other group with only pharmacological treatment. The benefits of Pulmonary rehabilitation were greater in patients with severe COPD. The more severe the disease, the greater the benefit.

\section{REFERENCES}

[1] Murray CJ, Lopez AD. Alternative projections of mortality and disability by cause 1990-2020: Global Burden of Disease Study. Lancet 1997;349(9064):1498-504.

[2] Lopez AD, Shibuya K, Rao C, et al. Chronic obstructive pulmonary disease: current burden and future projections. Eur Respir J 2006;27(2):397-412.

[3] Vestbo J, Hurd SS, Agustí AG, et al. Global strategy for the diagnosis, management and prevention of chronic obstructive pulmonary disease: GOLD executive summary. Am J Respir Crit Care Med 2013;187(4):347-65.

[4] Hill NS. Pulmonary rehabilitation. Proc Am Thorac Soc 2006;3(1):66-74.

[5] Lacasse Y, Goldstein R, Lasserson TJ, et al. Pulmonary rehabilitation for chronic obstructive pulmonary disease. Cochrane Database Syst Rev 2006;4:CD003793.

[6] Nici L, Donner C, Wouters E, et al. American Thoracic Society/European Respiratory Society statement on pulmonary rehabilitation. Am J Respir Crit Care Med 2006;173(12):1390-413. 
[7] Ries AL, Bauldoff GS, Carlin BW, et al. Pulmonary rehabilitation: Joint ACCP/AACVPR Evidence-Based Clinical Practice Guidelines. Chest 2007;131(Suppl 5):4S-42S.

[8] Troosters T, Casaburi R, Gosselink R, et al. Pulmonary rehabilitation in chronic obstructive pulmonary disease. Am J Respir Crit Care Med 2005;172(1):19-38.

[9] Gloeckl R, Marinov B, Pitta F. Practical recommendations for exercise training in patients with COPD. Eur Respir Rev 2013;22(128):178-86.

[10] Mahler DA, Ward J, Mejia-Alfaro R. Stability of dyspnea ratings after exercise training in patients with COPD. Med Sci Sports Exerc 2003;35(7):1083-7.

[11] de Blasio F, Polverino M. Current best practice in pulmonary rehabilitation for chronic obstructive pulmonary disease. Ther Adv Respir Dis 2012;6(4):221-37.
[12] Janaudis-Ferreira T, Hill K, Goldstein R, et al. Arm exercise training in patients with chronic obstructive pulmonary disease: a systematic review. J Cardiopulm Rehabil Prev 2009;29(5):277-83.

[13] McKeough ZJ, Bye PT, Alison JA. Arm exercise training in chronic obstructive pulmonary disease: a randomised controlled trial.Chron Respir Dis 2012;9(3):153-62.

[14] Katiyar SK, Bihari S. Role of pranayama in rehabilitation of COPD patients - a randomized controlled study. Indian J Allergy Asthma Immunol 2006;20(2):98-104. 